\title{
Comparison of laparoscopic percutaneous internal ring suturing method and open inguinal hernia repair in children under 3 months of age
} \author{
, Ayşe Karaman 3 (DD, ibrahim Karaman³ (ID) \\ ${ }^{1}$ Division of Pediatric Surgery, Ankara University School of Medicine, Ankara, Turkey \\ ${ }^{2}$ Division of Pediatric Surgery, Ondokuz Mayıs University School of Medicine, Samsun, Turkey \\ ${ }^{3}$ Clinic of Pediatric Surgery, Dr. Sami Ulus Research and Training Hospital, Ankara, Turkey
}

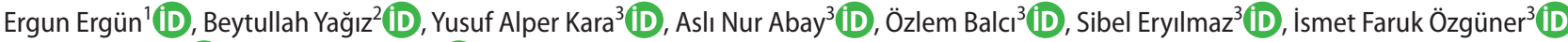

\begin{abstract}
Objective: Laparoscopic inguinal hernia repair in younger infants has not been completely accepted worldwide. The aim of this study was to evaluate the safety and feasiblity of laparoscopic percutaneous internal ring suturing method in children aged younger than 3 months and compare the recurrence and complication rates with open repair; which may still be mentioned as the gold standard procedure.

Material and Methods: A total of 387 children underwent inguinal hernia repair in the clinic between 2016 and 2019. One hundred and forty of them were under 3 months old and divided into two groups; children who underwent laparoscopic percutaneous internal ring suturing (Group 1) and open surgery (Group 2). Selection of the surgical method was regardless of weight, sex or any patient characteristics other than surgeon's choice. Operation durations, complications and recurrences were compared between the two groups.

Results: A total of 140 patients underwent surgery due to inguinal hernia. Group 1 included 85 and Group 2 included 55 children. There were two recurrences in each group ( $p>0.05)$. Operative durations were shorter in Group 1 for both; unilateral and bilateral repairs $(p<0.0001)$. There were no intraoperative complications in any group. There was one major postoperative complication in Group 2: iatrogenic undescended testis, and none was observed in Group 1. In the laparoscopic group, $47 \%$ of the children who were diagnosed to have unilateral hernia were revealed to have bilateral inguinal hernias $(n=31)$.
\end{abstract}

Conclusion: Laparoscopic percutaneous internal ring suturing method seems favourable in terms of operative time. It also has the advantage of detecting contralateral patent processus vaginalis or asymptomatic contralateral inguinal hernia.

Keywords: Infant, inguinal hernia, laparoscopy

Cite this article as: Ergün E, Yağız B, Kara YA, Abay AN, Balc Ö, Eryılmaz S, et al. Comparison of laparoscopic percutaneous internal ring suturing method and open inguinal hernia repair in children under 3 months of age. Turk J Surg 2021 37 (3): 215-221

\section{Corresponding Author}

Ergun Ergün

E-mail: ergunerguen@gmail.com

Received: 07.04 .2021

Accepted: 12.08 .2021

Available Online Date: 28.09 .2021

o Copyright 2021 by Turkish Surgical Society Available online at www.turkjsurg.com

DOI: 10.47717/turkjsurg.2021.5157

\section{INTRODUCTION}

Inguinal hernia $(\mathrm{IH})$ is one of the most common conditions which requires surgical intervention among children (1). The gold standard procedure has been open approach for years. Laparoscopic inguinal hernia repair has gained popularity recently but not totally accepted worldwide due to concerns as increased recurrence and complication risks, anaesthetic considerations and engaging the peritoneum. Its usage in younger infants and newborns have been under an even greater debate $(2-4)$.

Two of the authors have preferred laparoscopic percutaneous internal ring suturing (PIRS) method regardless of age, weight or sex of children since 2016 among variable laparoscopic approaches. The reasons are ability to complete the procedure with only one transumbilical trochar, excellent cosmetic results, comparable complication and recurrence rates with open approach and not dealing with the cord and the vessels.

Even though open approach has been performed for many years, recurrence is still a concern; even a bigger one in newborns or younger infants $(2,5)$. Open $॥$ repair in small children is a technically demanding procedure which brings the increased risk of complications such as testicular atrophy in addition to recurrence $(4,6)$. The studies with big data sets refer comparable results in terms of recurrence of open and laparoscopic $\mathrm{IH}$ repairs (7). Also, the fact that newborns have a higher possi- 
bility to have bilateral hernia may render laparoscopic approach reasonable since laparoscopy through the hernia sac may rarely be possible due to the fragile and thin sac of newborns.

The aim of this study was to evaluate the safety and feasiblity of laparoscopic PIRS method in children younger than 3 months and compare the recurrence and complication rates with open repair; which may still be mentioned as the gold standard procedure.

\section{MATERIAL and METHODS}

The study was performed in adherence to Declaration of Helsinki. Written informed consent was obtained from all participants' parents. Institutional review board and local ethical committee approval was granted. A total of 387 children underwent inguinal hernia repair in our clinic between 2016 and 2019. Among these children, 140 of them were under 3 months old. Patients younger than 3 months were divided into two groups; children who underwent laparoscopic PIRS (Group 1) and open surgery (Group 2). Laparoscopic PIRS was performed by two surgeons and open repair was performed by the other two. Patient selection was regardless of weight, sex or any patient characteristics other than comorbidities that may be a contraindication to laparoscopic surgery which we have not encountered in our series. Exclusion criterias were; age older than 3 months, presence of co-morbidities which were regarded as a contraindication for laparoscopy, and patients with a previous inguinal surgery.

\section{Surgical Technique}

Laparoscopic PIRS method: The patient was placed in supine position under general anesthesia. Preference of endotracheal intubation or laryngeal mask ventilation was at the discretion of the anaesthesiologist. Following local anesthesia with lidocaine, $5 \mathrm{~mm}$ umbilical trocar was placed by an open technique. Intraabdominal pressure was set between 6-8 $\mathrm{mm} \mathrm{CO}_{2}$ according to child's weight and age. A $5 \mathrm{~mm}$ telescope with $30^{\circ}$ angle was preferred. A $2 \mathrm{~mm}$ incision was made to the skin at the level of inguinal ring after inspection and a $22 \mathrm{G}$ angiocath needle was used to access preperitoneal space. A 3/0 or 4/0 non-absorbable monofilament suture was passed inside the needle to form a loop for ligation. Lateral-superior corner of the inguinal ring was the starting point and first half-round was created dissecting the peritoneum and encircling the internal ring including the peritoneum over the vas deferens and the spermatic vessels. Once the peritoneum over the vas deferens was dissected and passed, the loop was pushed into the peritoneal cavity and another suture starting from the same point but travelling counter-clockwise direction around the internal ring meeting with the first suture was introduced. The second needle and suture were also pushed in to the peritoneal cavity and, first needle and suture within is caught by the loop of the second suture. Then the first needle was withdrawn leaving its suture caught in the loop the second suture and first suture is taken out by the help of the second suture. Finally, the suture encircling the internal ring was tied outside, leaving the knot in the extraperitoneal space.

Open Technique: The patientis were placed in supine position, and external ring was exposed by dissecting medially along the Poupart's ligament by a standard inguinal transverse incision. The hernia sac was separated from the testicular vessels and vas deferens by using fine tissue forceps, and the hernia sac was dissected until the preperitoneal fat tissue was exposed. After confirming the absence of any sliding organs, the hernia sac was twisted and double suture-ligated with $3 / 0$ or $4 / 0$ absorbable suture. Fascia and other layers were closed with absorbable sutures.

\section{Statistical Analysis}

Statistical evaluation was conducted on SPSS for Windows 11.5 (Chicago, IL). Categorical variables between the groups were compared by Chi Square test, normally distributed nominal variables were compared with independent t-test, non normally distributed variables were compared with Mann-Whitney $U$ test. $p$ value was set as $<0.05$ as a statistical significance indicator.

\section{RESULTS}

Laparoscopic PIRS procedure was performed in 85 children and open repair in 55 . Male to female ratio of the study group was 5 (117 males and 23 females). Mean age of the children was 53 days (range; 14-90 days) and mean weight was $4.3 \mathrm{~kg}$ (3-5.4). Detailed data on patient characteristics is given in Table 1. The preference of the surgical method was at the discretion of the surgeons; one team performed laparoscopic surgery and the other preferred open approach regardless of patient characteristics unless refused by the parents or contraindicated due to co-morbidites.

Although the rate of bilaterality was found lower on preoperative evaluation (28/140; 20\%), the rate was increased to $42 \%(59 / 140)$ due to incidental repair of contralateral patent processus vaginalis (CPPV) in the laparoscopy group. In one patient with incarcerated hernia, the procedure was converted to open to perform resection of the necrotic intestines (Conversion rate: 1/85; 1\%).

\section{DISCUSSION}

Laparoscopic $\mathrm{IH}$ repair in children has gained worldwide popularity recently. One of the most popular laparoscopic techniques in children is PIRS, described by Patkowski et al., which was accepted and underwent many modifications by many others $(4,8)$. Despite the popularity of this method, open surgery is still the first choice in many centers. Laparoscopic repair has evolved significantly with many modifications, and results are comparable to each other without demonstrating any significant advantage $(4,8-14)$.

Although there are studies on laparoscopic $\mathrm{IH}$ repair in younger infants and neonates, very few performed percutaneous techniques (2-4,6,15-17). Zenitani et al. have reported comparable re- 


\begin{tabular}{|c|c|c|c|c|}
\hline & \multicolumn{2}{|c|}{ Group 1 (Laparoscopic PIRS) } & Group 2 (Open repair) & $\mathrm{p}$ \\
\hline $\mathrm{N}$ & \multicolumn{2}{|c|}{85} & 55 & \\
\hline Male/Female & \multicolumn{2}{|c|}{$73 / 12$} & $44 / 11$ & \\
\hline Side & $\begin{array}{c}\text { Preoperative: } \\
\text { Right: } 42 \\
\text { Left: } 24 \\
\text { Bilateral: } 19\end{array}$ & $\begin{array}{c}\text { Postoperative: } \\
\text { Right: } 22 \\
\text { Left: } 13 \\
\text { Bilateral: } 50\end{array}$ & $\begin{array}{l}\text { Right: } 30 \\
\text { Left: } 16 \\
\text { Bilateral: } 9\end{array}$ & \\
\hline Intraoperative complication & \multicolumn{2}{|c|}{ None } & None & \\
\hline Intraoperative finding & \multicolumn{2}{|c|}{$\begin{array}{l}\text { Amyand's hernia }(n=1) \\
\text { Ischemic intestine }(n=1)\end{array}$} & Amyand's hernia $(n=1)$ & \\
\hline $\begin{array}{l}\text { Operative time } \\
\text { Unilateral } \\
\text { Bilateral }\end{array}$ & \multicolumn{2}{|c|}{$\begin{array}{l}\text { Mean: } 24 \pm 4.14 \text { minutes }(17-34) \\
\text { Mean: } 33 \pm 3.70 \text { minutes }(29-44)\end{array}$} & $\begin{array}{l}\text { Mean: } 42 \pm 5.27 \text { minutes (35-58) } \\
\text { Mean: } 65 \pm 8.55 \text { minutes (51-79) }\end{array}$ & $\begin{array}{l}p<0.0001 \\
p<0.0001\end{array}$ \\
\hline Conversion to open surgery & \multicolumn{2}{|c|}{$\mathrm{n}=1$ (necrotic intestines) } & - & \\
\hline Major postoperative complications & \multicolumn{2}{|c|}{$\mathrm{n}=0$} & $\begin{array}{l}\qquad \mathrm{n}=1 \\
\text { iatrogenic undescended testis }\end{array}$ & \\
\hline Recurrence & \multicolumn{2}{|c|}{$\begin{array}{c}\mathrm{n}=2 \text { (1 and } 11 \text { months after the surgery) } \\
\text { (both repaired laparoscopically) }\end{array}$} & $\begin{array}{c}\mathrm{n}=2 \text { (1 week and } 3 \text { months after the surgery) } \\
\text { (both repaired laparoscopically) }\end{array}$ & $p>0.05$ \\
\hline
\end{tabular}

sults with open surgery in terms of safety and efficacy in infants younger than 6 months in their series of 120 patients and reduced incidence of metachronous contralateral inguinal hernia $(\mathrm{MCIH})(16)$. They have reported the recurrence rate as $0.83 \%$ ( $n=$ $1 / 120$ ) without any major complications. Patkowski et al. have stated no recurrences and only one minor intraoperative complication in their study with 25 infants (15). Shibuya et al. have presented their study on percutaneous $\mathrm{H}$ repair in extremely low birth weight infants with 17 children versus 22 who underwent open surgery and showed one recurrence (5.9\%) and one postoperative vomiting during postoperative period which may be attributed to general anaesthesia (17). Our study with 85 children under 3 months of age revealed a recurrence rate of $2.3 \%$. Studies on other laparoscopic $\mathrm{IH}$ repair methods in younger infants and newborns present recurrence rates between 1-4\% $(1-4,6,18)$. Considering the fact that $\mathrm{H}$ repair in newborns and infants has higher recurrence risk, our results seem comparable with the literature but tend to be higher than the mentioned studies on percutaneous method $(0.83 \%, 0 \%, 5.9 \%$ and $2.3 \%$ respectively). When we compared the results with the open group, the recurrence rates were not statistically significant ( $p=$ 0.65). Even though low weight, prematurity and young age are considered as predisposing risk factors for recurrence, Choi et al. have revealed the opposite and found higher recurrence rates in older children (4\% vs. 1\%) (1). The recurrence rates were not statistically significant but they attributed it to the relatively small sample size.

Open herniorrhaphy is a technically challenging procedure, especially in small male infants due to fragile and thin hernia sac and vulnerable vas deferens with puny vessels. Very high percentage of complications and recurrences after $\mathrm{IH}$ repair have been reported either by open or laparoscopic approach in male patients $(19,20)$. Miyake et al. have reported 9 recurrences in total of 2067 children and all of the children who suffered from recurrence were boys and Amano et al. have presented only 6 recurrences in 2028 cases and only one of them was a girl $(19,20)$. Very thin and fragile hernia sac and delicate dissection of vas deferens and vessels from the sac may be very difficult and challenging. In a study, vas deferens or epididymis has been found in $0.53 \%$ of excised hernia sacs (21). Also, as neonates and younger infants are more prone to incarceration, surgery may become more complicated and troublesome due to edematous and fragile peritoneum (16). All of these factors contribute to the increased risk of complications such as iatrogenic undescended testis and testicular atrophy secondary to a complicated surgery which is already technically demanding $(6,21,22)$. Recurrence rates of open surgery have been reported between $0.8-3.8 \%$ in younger infants (23). On the other hand, since no dissection is needed in the PIRS procedure; it may be safer and easier in children with history of incarcerated inguinal hernia. In the present series, there were not any major postoperative complications such as testicular atrophy or morbidity that required additional surgeries such as hydrocele, ascended or atrophic testis in the laparoscopic PIRS group. In the open surgery group, one child suffered from iatrogenic undescended testis and underwent additional surgery at one year of age (1.8\%). Standard inguinal orchiopexy was performed and no sign of testicular atrophy was recorded after 6 months of follow up. Regarding complications, 
open surgery seems to have higher possibility of major complications despite total complication possibility seems similar (24). Complications such as iatrogenic undescended testis, testicular atrophy and bladder rupture have been reported $(19,24,25)$.

There was one case in the study which required conversion to open surgery. This was a two-month-old boy and he was presented with incarcerated hernia. Incarcerated segment was reducted under laparoscopic vision but the intestines seemed ischemic and laparotomy was performed to evaluate the intestines. Affected segment was evaluated to be necrotic and resected. In an 18-day-old boy with incarcerated hernia, appendix was found in the hernia sac with significant adhesions to the right inguinal canal. After laparoscopic reduction and excision of appendix, $\mathrm{IH}$ repair was decided not to be performed because of the inflammated area. After one week, laparoscopic PIRS was performed without incidence.

Another clear advantage of laparoscopic $\mathrm{IH}$ repair is the availability to evaluate both inguinal canals properly. It allows contralateral repair of $\mathrm{IH}$ or PPV simultaneously. Although transinguinal laparoscopic exploration of the contralateral inguinal canal is an option in open surgery, it may not always be possible in infants whose hernia sac may be fragile and very thin. Due to technical difficulties and/or thin/ fragile hernia sac, it may be difficult to perform even in older children (26). As Endo et al. have stated, even if transinguinal exploration is performed successfully, cPPV rates may be different in transinguinal exploration and laparoscopic exploration due to the technical difficulties (23). They have presented a 21.6\% contralateral PPV incidence in transinguinal exploration and $47 \%$ in laparoscopic surgery while Gollu et al. have stated a similar $28.3 \%$ positivity in transinguinal exploration $(23,26)$. In our series, the rate was $47 \%$ (31/66); exactly the same as in the series of Endo et al. Considering the more common bilaterality in infants and newborns and challenges of performing transinguinal contralateral exploration, the advantages of laparoscopy may become more prominent. In our institution, neither contralateral transinguinal exploration nor open exploration of the other side is a standard approach. So, asymptomatic contralateral hernias or PPVs of children who undergo open surgery remain undetected until they become symptomatic. This situation may lead to the burden of another surgery; to the family, hospital and the child, and the results of laparoscopic PIRS group shows that $47 \%$ of children with preoperative diagnosis of unilateral hernia have undergone bilateral hernia repair. Other studies on laparoscopic $\mathrm{IH}$ repair in small infants have also shown nearly similar rates $(20-61 \%)(1,6,16)$. Studies with no age limitation shows rates between 17-43\% (27). By the laparoscopic approach, it seems possible to reduce the possibility of $\mathrm{MCIH}$ and reoperation of the children, which comes along with extra anesthesia exposure of the child, additional anxiety of the parents and increased risks of possible morbidities (27). Amano et al. have stated that regarding their 40\% cPPV rate, the open group may be expected to develop contralateral hernia in same rate but only $12 \%$ of these open group developed $\mathrm{MCH}$ (20). The repair of CPPV remains controversial regarding this data. However, the authors think that since PIRS is a minimally invasive method with very low testicular atrophy and major complication risks, it may be suggested to perform a prophylactic cPPV repair. Another debate on laparoscopic methods is about the costs. Laparoscopy may seem more expensive than open approach but it is not considering the possibility of a reoperation due to development of a clinically significant inguinal hernia. In addition, usage of reusable materials as we do may help to decrease costs.

Recurrence is a major problem of $\mathrm{IH}$ repair in young infants. Using non absorbable sutures and giving extra caution to medial aspect of inguinal ring may help to prevent recurrences, especially in male infants $(4,6,18)$. In the laparoscopic group, there were two recurrences, and reoperation revealed that the peritoneum at the medial side of the inguinal canal was ripped and it led to loosen the entire suture. Although recurrent hernias of the open group were observed to have occured in the medial side too, lateral side of these defects were closed and smaller gaps were observed. The repair of these recurrent hernias technically were not more difficult than a primary operation as it would be expected the opposite in open repair. Thus, laparoscopic surgery of recurrent inguinal hernias also seems easier than the open approach.

Waiting the child to grow is another controversy in neonatal $\mathrm{IH}$ repair (28). Complication and recurrence risks are higher in young infants as well as the incarceration rates $(3,28)$. Thus, many surgeons do not follow children with inguinal hernia more than 2 weeks or until the children reach acceptable weight as long as they do not have major comorbidities $(2,29)$. Laparoscopic repair with 3 ports has been found to be safe and feasible in these children (2-4,6). However, considering the small body size, elasticity of the abdominal wall and small intra-abdominal space, intracorporeal suturing in these children is also technically demanding. PIRS method seems to be a technically easier method with comparable outcomes $(15,16)$. Another advantage of PIRS is relatively less violation of the abdominal wall integrity since only one trochar is introduced.

In the present study, mean operative durations were found significantly shorter in laparoscopic PIRS group than the open group for both unilateral and bilateral hernias (24 vs. 42 and 33 vs. 65 mins respectively, $p<0.0001$ ). In previous studies, laparoscopic $\mathrm{IH}$ repair has been reported to last generally longer or equal with open surgery $(19,20)$. Intraperitoneal techniques requiring intracorporeal suturing, 3 port procedures and some newly introduced techniques might be responsible for these longer durations (30-33). The present study may indicate that 
laparoscopic PIRS method may be superior to open approach in terms of operative times. The authors believe that this may be a result of the simplicity of the technique and extraperitoneal closure of inguinal canal without additional instrumentation other than a needle and increased bilaterality in the smaller infants. Because it is possible to repair bilateral hernias in the same setting in laparoscopic surgery while open surgery requires two different incisions and two seperate operations from beginning to the end. Reduced anaesthetical times are especially important for younger infants. Also, we did not observe any anaesthetical challenge which might be a result of an experienced team and short operative times.

Another concern which is very difficult to clarify in laparoscopic surgery is whether the position of the cord is changed or not. Kinking, distortion, angulation or some other malposition of the cord may be catastrophic for the patient, and it may not be easily recognized intraoperatively. Li et al. have evaluated the position of the cord and testicular blood flow in their study and found that neither the position of the cord nor the testicular blood flow was seemed to be affected in percutaneous $\mathrm{IH}$ repair (34).

There are some limitations of the study. First, the study is retrospective and selection bias can not be ignored. But all operations were performed by four surgeons and two of them performed laparoscopic surgery to all of their patients and the other two performed open surgery regardless of age and sex. This natural division may bring a relative randomization to the study even though it is not a randomized controlled study. Relatively small number of patients with short follow up time are other limitations. Since all recurrences and morbidities due to the operations tend to present within the postoperative first year, we think that the data may be reliable in terms of recurrences and postoperative complications. Absence of data on prematurity and birth weight and the missing data on development of $\mathrm{MCIH}$ after open surgery are the major limitations of the present study.

\section{CONCLUSION}

Laparoscopic PIRS method seems favourable in terms of operative time and detecting CPPVor asymptomatic contralateral $\mathrm{IH}$ in children under 3 months of age. Recurrence rates are comparable with open surgery without any major complications. Concerning $\mathrm{MClH}$ in children, prospective randomized controlled studies with long follow up, especially for young infants and newborns, are necessary. Another missing data on laparoscopic $\mathrm{IH}$ repair by any method is its effects on the reproductive system. Even though it seems safer, it is a well known fact that open inguinal surgery is one of the most common reasons of male infertility (23). Thus, from now on, we should emphasise on the effects of laparoscopic $\amalg H$ repair on male reproductive system by designing long term prospective studies.
Ethics Committee Approval: The ethical approval for this study was obtained from SUAM Committee of Medical Residency Training (Decision No: 2020/01-2, Date: 22.01.2020).

Peer-review: Externally peer-reviewed.

Author Contributions: Concept - All of authors; Design - E.E., B.Y., Y.A.K.; Supervision - E.E., B.Y., Y.A.K., I.K., A.N.A.; Data Collection and/or Processing - All of authors; Analysis and/or Interpratation - Y.A.K.; A.N.A., Ö.B.; S.E.; A.K. Literature Review - E.E., B.Y., Y.A.K., A.N.A., S.E., Ö.B.; Writing Manuscript - Ö.B., S.E., IF.Ö., A.K., I.K.; Critical Reviews - All of authors.

Conflict of Interest: The authors have no conflicts of interest to declare.

Financial Disclosure: The authors declared that this study has received no financial support.

\section{REFERENCES}

1. Choi W, Hall NJ, Garriboli M, Ron O, Curry Jl, Cross K, et al. Outcomes following laparoscopic inguinal hernia repair in infants compared with older children. Pediatr surg int 2012; 28(12): 1165-9. [CrossRef]

2. Turial S, Enders J, Krause K, Schier F. Laparoscopic inguinal herniorrhaphy in premature infants. Eur J Pediatr Surg 2010; 20(06): 371-4. [CrossRef]

3. Chan I, Lau C, Chung P, Chan K, Lan L, Wong K, et al. Laparoscopic inguinal hernia repair in premature neonates: is it safe? Ped Surg Int 2013; 29(4): 327-30. [CrossRef]

4. Esposito C, Turial S, Escolino M, Giurin I, Alicchio F, Enders J, et al. Laparoscopic inguinal hernia repair in premature babies weighing $3 \mathrm{~kg}$ or less. Ped Surg Int 2012; 28(10): 989-92. [CrossRef]

5. Phelps S, Agrawal M. Morbidity after neonatal inguinal herniotomy. J Pediatr Surg 1997; 32(3): 445-7. [CrossRef]

6. Turial S, Enders J, Krause K, Schier F. Laparoscopic inguinal herniorrhaphy in babies weighing $5 \mathrm{~kg}$ or less. Surg Endosc 2011; 25(1): 72-8. [CrossRef]

7. Yang C, Zhang H, Pu J, Mei H, Zheng L, Tong Q. Laparoscopic vs open herniorrhaphy in the management of pediatric inguinal hernia: a systemic review and meta-analysis. J Pediatr Surg 2011; 46(9): 1824-34. [CrossRef]

8. Patkowski D, Czernik J, Chrzan R, Jaworski W, Apoznański W. Percutaneous internal ring suturing: a simple minimally invasive technique for inguinal hernia repair in children. J Laparoendosc Adv Surg Tech 2006; 16(5): 513-7. [CrossRef]

9. Rao R, Smith M, Markel TA, Gray BW, Landman MP. Modified percutaneous internal ring suturing with peritoneal injury in children: matched comparison to open hernia repair. Surg Endosc 2020; 1-6. [CrossRef]

10. Cui Z, Liu Y, Zhang W, Sun F. Single-port laparoscopic percutaneous double ligation for pediatric inguinal hernias: report of a new technique and early results. Hernia 2016; 20(4): 579-84. [CrossRef]

11. Shen W, Ji H, Lu G, Chen Z, Li L, Zhang H, Pan J. A modified single-port technique for the minimally invasive treatment of pediatric inguinal hernias with high ligation of the vaginal process: the initial experience. Eur J Pediatr Surg 2010; 169(10): 1207-12. [CrossRef]

12. Xu C, Xiang B, Jin S-G, Luo Q-C, Zhong L. Transumbilical two-port laparoscopic percutaneous extraperitoneal closure: a new technique for inguinal hernia repair in children. J Laparoendosc Adv Surg Tech 2013; 23(4): 392-6. [CrossRef] 
13. Shalaby R, Abd Alrazek M, Elsaied A, Helal A, Mahfouz M, Ismail M, et al. Fifteen years experience with laparoscopic inguinal hernia repair in infants and children. J Laparoendosc Adv Surg Tech 2018; 28(1): 1015. [CrossRef]

14. Liu W, Wu R, Du G. Single-port laparoscopic extraperitoneal repair of pediatric inguinal hernias and hydroceles by using modified Kirschner pin: a novel technique Hernia 2014; 18(3): 345-9. [CrossRef]

15. Patkowski D, Chrzan R, Jaworkki W, Apoznański W, Czernik J. Percutaneous internal ring suturing for inguinal hernia repair in children under three months of age.Adv Clin Exp Med 2006; 15(5): 851-6. [CrossRef]

16. Zenitani M, Saka R, Sasaki T, Takama Y, Tani G, Tanaka N, et al. Safety and efficacy of laparoscopic percutaneous extraperitoneal closure for inguinal hernia in infants younger than 6 months: A comparison with conventional open repair. Asian J Endosc Surg 2019; 12(4): 439-45. [CrossRef]

17. Shibuya S, Miyazaki E, Miyano G, Imaizumi T, Mikami T, Ochi T, et al. Comparison of laparoscopic percutaneous extraperitoneal closure versus conventional herniotomy in extremely low birth weight infants. Pediatr Surg Int 2019; 35(1): 145-50. [CrossRef]

18. TreefW, Schier F. Characteristics of laparoscopic inguinal hernia recurrences. Pediatr Surg Int 25(2): 149-52. [CrossRef]

19. Miyake H, Fukumoto K, Yamoto M, Nouso H, Kaneshiro M, Nakajima $H$, et al. Comparison of percutaneous extraperitoneal closure (LPEC) and open repair for pediatric inguinal hernia: experience of a single institution with over 1000 cases. Surg Endosc 2016; 30(4): 1466-72. [CrossRef]

20. Amano H, Tanaka Y, Kawashima H, Deie K, Fujiogi M, Suzuki K, et al. Comparison of single-incision laparoscopic percutaneous extraperitoneal closure (SILPEC) and open repair for pediatric inguinal hernia: a single-center retrospective cohort study of 2028 cases. Surg Endosc 201731(12): 4988-95. [CrossRef]

21. Steigman CK, Sotelo-Avila C, Weber TR. The incidence of spermatic cord structures in inguinal hernia sacs from male children. Am J Surg Pathol 1999; 23(8): 880. [CrossRef]

22. Nagraj S, Sinha S, Grant H, Lakhoo K, Hitchcock R, Johnson P. The incidence of complications following primary inguinal herniotomy in babies weighing $5 \mathrm{~kg}$ or less. Pediatr Surg Int 2006; 22(6): 500-2. [CrossRef]

23. Endo M, Watanabe T, Nakano M, Yoshida F, Ukiyama E. Laparoscopic completely extraperitoneal repair of inguinal hernia in children: a single-institute experience with 1,257 repairs compared with cutdown herniorrhaphy. Surg Endosc 2009; 23(8): 1706-12. [CrossRef]
24. Feng S, Zhao L, Liao Z, Chen X. Open versus laparoscopic inguinal herniotomy in children: a systematic review and meta-analysis focusing on postoperative complications. Surg Laparosc Endosc Percutan Tech 2015; 25(4):275-80. [CrossRef]

25. Miyano G, Yamataka A, Okada Y, Shimotakahara A, Kaneko K, Lane GJ, et al. Sigmoidocolocystoplasty for augmentation of iatrogenic small capacity bladder caused by direct injury to the bladder during inguinal hernia repair: long-term follow-up. Pediatr Surg Int 2004; 20(1): 61-4. [CrossRef]

26. Gollu G, Ates U, Bahadir K, Ergun E, Yagmurlu A, Cakmak M, Aktug T, Dindar H, Bingol-Kologlu M (2019) Transinguinal laparoscopic evaluation of contralateral side during unilateral inguinal hernia repair for children. J pediatr urol 15(5):561-566. [CrossRef]

27. Chong AJ, Fevrier HB, Herrinton LJ. Long-term follow-up of pediatric open and laparoscopic inguinal hernia repair. J Pediatr Surg 2019; 54(10): 2138-44. [CrossRef]

28. Pastore V, Bartoli F. Neonatal laparoscopic inguinal hernia repair: a 3-year experience. Hernia 2015; 19(4): 611-5. [CrossRef]

29. Uemura S, Woodward A, Amerena R, Drew J. Early repair of inguinal hernia in premature babies. Pediatr Surg Int 1999; 15(1): 36-9. [CrossRef]

30. Timberlake MD, Herbst KW, Rasmussen S, Corbett ST. Laparoscopic percutaneous inguinal hernia repair in children: review of technique and comparison with open surgery J Pediatr Urol 2015; 11(5): 262-7. [CrossRef]

31. Tsai YC, Wu C-C, Shei-Dei Yang S. Open versus minilaparoscopic herniorrhaphy for children: a prospective comparative trial with midterm follow-up evaluation. Surg Endosc 2010; 24(1):21. [CrossRef]

32. Alzahem A. Laparoscopic versus open inguinal herniotomy in infants and children: a meta-analysis. Pediatr Surg Int 2011; 27(6): 605-12. [CrossRef]

33. Shalaby R, Ismail M, Dorgham A, Hefny K, Alsaied G, Gabr K, et al. Laparoscopic hernia repair in infancy and childhood: evaluation of 2 different techniques. J Pediatr Surg 2010; 45(11): 2210-6. [CrossRef]

34. Li C, Xu L, Peng Y, Liang X, Lin W. Effects of single-port laparoscopic percutaneous extraperitoneal closure on the orientation of the vas deferens and testicular perfusion and volume: Experience from a single center. J Pediatr Urol 2016; 12(3): 170-4. [CrossRef] 


\section{ORIJINAL ÇALIŞMA-ÖZET}

Turk J Surg 2021; 37 (3): 215-221

\section{3 aydan küçük bebeklerde laparoskopik perkütan iç halka dikişi yöntemiyle açık inguinal herni onarımının karşılaştırılması}

Ergun Ergün ${ }^{1}$, Beytullah Yağız ${ }^{2}$, Yusuf Alper Kara ${ }^{3}$, Aslı Nur Abay ${ }^{3}$, Özlem Balcı ${ }^{3}$, Sibel Eryılmaz ${ }^{3}$, İsmet Faruk Özgüner ${ }^{3}$, Ayşe Karaman $^{3}$, İbrahim Karaman ${ }^{3}$

${ }^{1}$ Ankara Üniversitesi Tıp Fakültesi, Çocuk Cerrahisi Bilim Dalı, Ankara, Türkiye

${ }^{2}$ Ondokuz Mayıs Üniversitesi Tıp Fakültesi, Çocuk Cerrahisi Bilim Dalı, Samsun, Türkiye

${ }^{3}$ Dr. Sami Ulus Eğitim ve Araştırma Hastanesi, Çocuk Cerrahisi Kliniği, Ankara, Türkiye

\section{ÖZET}

Giriş ve Amaç: Küçük bebeklerde laparoskopik inguinal herni onarımı dünya çapında tam olarak kabul görmemiştir. Bu çalışmanın amacı, 3 aydan küçük çocuklarda laparoskopik perkütan iç halka süturu yönteminin güvenilirliğini ve uygulanabilirliğini değerlendirmek ve halen altın standart prosedür olarak kabul edilen açık onarım ile rekürrens ve komplikasyon oranlarını karşılaştırmaktır.

Gereç ve Yöntem: Klinikte 2016-2019 yılları arasında toplam 387 çocuğa inguinal herni onarımı yapıldı. Bunların 140'ı 3 aylıktan küçüktü ve bu hastalar iki gruba ayrıldı; laparoskopik perkütan iç halka süturu (Grup 1) ve açık cerrahi (Grup 2) yapıldı. Cerrahi yöntemin seçimi, cerrahın rutinde kullanmakta olduğu yöntem dışındaki ağırlık, cinsiyet veya herhangi bir hasta özelliğinden bağımsız olarak yapıldı. Operasyon süreleri, komplikasyonlar ve rekürrensler iki grup arasında karşılaştırıldı.

Bulgular: Toplam 140 hasta, kasık fıtığı nedeniyle ameliyat edildi. Grup 1'de 85 ve Grup 2'de 55 çocuğu bulunmaktaydı. Her grupta iki rekürrens saptandı ( $p>0,05)$. Grup 1'de tek taraflı ve çift taraflı onarımların her ikisi için de ameliyat süreleri daha kısaydı ( $p<0,0001)$. Iki grupta da intraoperatif komplikasyon görülmedi. Grup 2'de bir majör postoperatif komplikasyon görüldü; iyatrojenik inmemiş testis, Grup 1'de postoperatif majör komplikasyon görülmedi. Laparoskopik grupta tek taraflı fıtık tanısı alan çocukların \% 47'sinde bilateral kasık fıtığı $(n=31)$ olduğu saptandı.

Sonuç: Laparoskopik perkütan internal ring sütur yöntemi ameliyat süresi açısından uygun bir yöntem olarak görünmektedir. Ayrıca kontralateral patent prosessus vaginalis veya asemptomatik kontralateral inguinal herninin eş zamanlı tespit edilmesi avantajını taşımaktadır.

Anahtar Kelimeler: Bebekler, inguinal herni, laparoskopi

Doi: 10.47717/turkjsurg.2021.5157 